
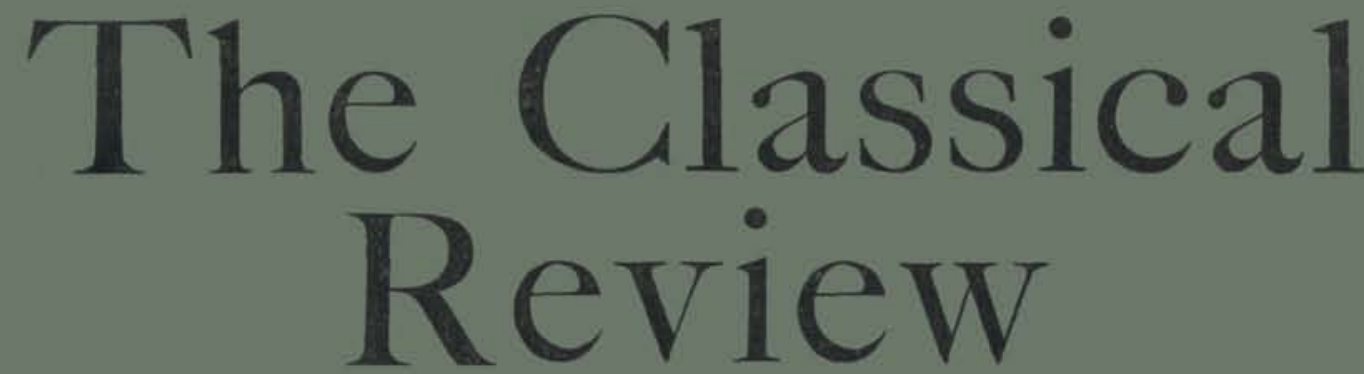

Editors ( E. HARRISON, M.A., Trinity College, Cambridge

C. J. FORDYCE, M.A., 3 The University, Glasgow, W. 2

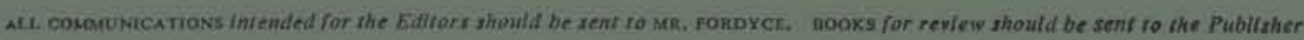

\title{
BOARD OF MANAGEMENT
}

Pror, D. S, ROBERTSON, M.A. (Chairman), representins the Cambridse Phllolokical Sodety 5. G. BARRINGTON-WARD, M.A. (Hon. Treas.), Prop. J. F. DOBSON, M.A.: | Repretentins the Councll of the Prov, H. A. ORMEROD, M.A. F.S.A., F. H. SANDBACH, M.A. (Hon. Sec.),
Plor. E. H. WARMINGTON, M.A.

E, A. BARBER, M.A., F.B.A., representing the Oxford Philotoricat Soctety

Wirh she co-operation of

Prov. J. I. MICHIE, University of Oueensland, ProF. E. K. RAND. Harvard University, and Pron. B. D. MERITT, Institute for Adivanced Situdy, Princeton

\section{CONTENTS}

THE MAKING OF A LEXICON. H. STUART JONES WHO'S WHO IN HOMER. P.J. MACDONELL

INIERLINEAR HIATUS IN GRFEK TRAGIC TRIMETERS. E. HARRUSON . 22 THE BACKGROUND OF VALERIUS FLACCUS i.10. A. Y. CAMPBELL,

D, S. ROBERTSON * * * * * * * 25

THUCYDIDES i.36.3, E. A. THOMPSON * . . . . . 27

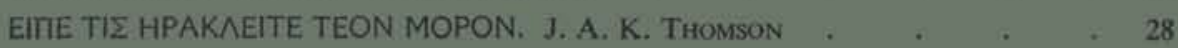

REVIEWS:

A Greek-English Lexicon, pan 10 (Liddell \& Scot). E. HARrison, 28; Zu den Rechtsproblemen in Aischylos disamemnon (Daube), G. THOMsoN, 30; The Quallty of Mercy (Macurdy), E. S. Forster, 31: Plato, Selecied Passages (Livingstone). D. TAkruNr, 32; Asklepiades of Samos (Wallaco), E. S. Forstek, 33: Evangellum secundum Matrhacum (Legg), H. F. D. SPARKS, 34; Les Popyrus Fouad I,

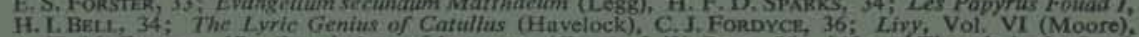
A. H. MeDonkib. 37 : Foundations of Language (Griy), J. W. PIRIE, 38; Life and Thought in the Greek and Roman World (Cary and Haarhof). A. F. Grisy, 40; The Tholos of Athens (Thompson), D. S. and Roman World (Cary and Haarhoin), A. C. Griss, 40; The Tholos of Athens (Thompson), D. S. ROnERTSON, 41; Perachora (Payne), W. L. CuTrLe, 41; The Greek City (Jones), A. N. SHrawnv-

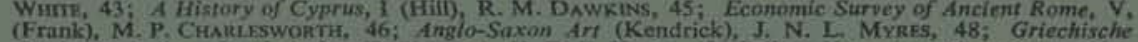

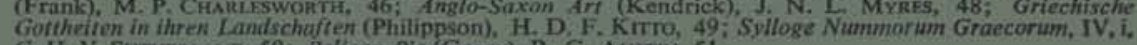
C. H. V. Suthren AND, S0; Pelican Pie (Geary), R. G. AustiN, 51.

SHORT REVIEWS . . . . . . . . . . . . 52

SUMMARIES OF PERIODICALS . . . . . . . . . . 53

CORRESPONDENCE . . . . . . . . . . . 55

BOOKS RECEIVED $\quad$. . . . . . . . . . . 55

OXFORD : AT THE CLARENDON PRESS

LONDON, NEW YORK, TORONTO, AND MELBOURNE : HUMPHREY MILFORD

Price for single numbers, 3s. net. Yearly subseription, 12s. net, post frea; U.S.A., \$2.55. Combined yearly subscription for the CLASSICAL QUARTERLY and the CLASSICAL REVIEW, 25s. net, post free; U.S.A., 55.32 


\section{THE}

\section{G L A S S I C A L R E V I E W \\ EDITED BY \\ E. HARRISON AND C. J. FORDYCE}

BOARD OF MANAGEMENT

PRor. D. S. ROBERTSON, M.A, F.B.A. (Chairman)

J. G. BARRINGTON-WARD, M.A. (Hon. Treasurer)

F. H. SANDBACH, M.A. (Hon. Secretary)

Prof. J. F. DOBSON, M.A.; Prof. H. A. ORMEROD, M.A., F.S.A. Prof. E. H. WARMington, M.A.; E. A. BARBER, M.A., F.B.A.

With the co-operation of

PRof. J. L. MICHIE, University of Queensland,

PRoF. E. K. RAND, Harvard University and

Prof. B. D. MERITT, Institute of Advanced Study, Princeton

VOLUME LV

Published in co-operation with the Classical Association OXFORD : AT THE CLARENDON PRESS 


\section{OXFORD UNIVERSITY PRESS}

AMEN HOUSE, E.C. 4

LONDON EDINBURGH GLASGOW NEW YORK TORONTO MELBOURNE CAPETOWN BOMBAY

CALCUTTA MADRAS

HUMPHREY MIEFFORD

PUBLISHER TO THE UNIVERSITY

PRINTED IN GREAT BRITAIN 


\section{TABLE OF CONTENTS}

\section{Number 1}

The making of a lexicon. H. STUART Jones Who's who in Homer. P. J. MACDONELL . Interlinear hiatus in Greek tragic trimeters.

E. HARRISON

The background of Valerius Flaccus i. 10. A. Y. CAMPBELL, D. S. Robertson . THUCYDIDES i. 36. 3. E. A. THOMPSON . EITE TIE HPAKAEITE TEON MOPON. J.A. K. THOMSON

Reviews:

A Greek-English Lexicon, part to (Liddell \& Scott), E. HARRISON, 28; Zu den Rechtsproblemen in Aischylos' Agamemnon (Daube), G. Thomson, 3o; The Quality of Mercy (Macurdy), E. S. Forster, $3 \mathrm{I}$; Plato, Selected Passages (Livingstone), D. TARRANT, 32 ; Asklepiades of Samos (Wallace), E. S. FORSTER, 33 ; Evangelium secundum Matthaeum (Legg), H. F. D. SPARKS, 34; Les Papyrus Fouad I, H. I. BELL, 34; The Lyric Genius of Catullus (Havelock), C. J.
PAGE

Fordyce, 36 ; Livy, Vol. VI (Moore), A. H. MCDONALD, 37 ; Foundations of Language (Gray), J. W. PIRIE, 38 ; Life and Thought in the Greek and Roman World (Cary and Haarhoff), A. F. Giles, 40; The Tholos of Athens (Thompson), D. S. RoBerTson, 4I ; Perachora (Payne), W. L. CuTTLE, 4I ; The Greek City (Jones), A. N. SHERWIN-WHITE, 43; A Hisiory of Cyprus, I (Hill), R. M. DawkINS, 45; Economic Survey of Ancient Rome, V (Frank), M. P. ChaRLesworth, 46; Anglo-Saxon Art (Kendrick), J. N. L. MYRES, 48; Griechische Gottheiten in ihren Landschaften (Philippson), H. D. F. KITTo, 49; Sylloge Nummorum Graecorum, IV, i, C. H. V. Sutherland, 50; Pelican Pie (Geary), R. G. Austin, 51.

Short reviews $\quad$. $\quad$. $\quad$. 52

Summaries of periodicals . $\quad . \quad$. 53

Correspondence . . . . . . 55

Books received $\quad$. $\quad . \quad$. $\quad$. $\quad$. 55

\section{Number 2}

Notes and news

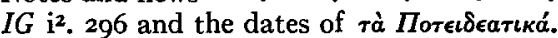
A. W. Gomme

Archilochus, fr. 56. D'A. W. THOMPSoN Three passages of the Birds. D. S. ROBERTSON

The Delphian succession in the opening of the Eumenides. D. S. ROBERTSON

Passages of Catullus, Martial, and Plautus. F. A. Tond .

Notes on Sallust, Statius, and Vegetius. W. MOREI

\section{Reviews:}

Minor Attic Orators, I (Maidment), E. C. Marchant, 75 ; Plato and Parmenides (Cornford), J. TAte, 76; Athenaeus, VII (Gulick), E. Harrison, 78; Procopius, VII (Dewing), D. S. ROBERTSON, 79; Manetho (Waddell) and Ptolemy, Tetrabiblos (Robbins), H. J. RosE, $84 ; H N \Delta I \Delta A \Sigma K \Omega N$ (Björck), W. L. LORIMER, 85 ; A Chronology of the Plays of Plautus (Buck), W.
BEARE, 86; The Odes of Horace translated (Marsh), L. P. Wilkinson, 87; Boethius (Barrett), R. M. HENRY, 88; The Greek Trireme (Morrison), W. W. TARN, 89; Archaic Sculpture in Boeotia (Grace), P. N. URE, 90; The Emperor Claudius (Scramuzza), M. P. CharlesWORTH, 9I ; Recherches sur le culte impérial (Pippidi), M. P. Charlesworth, 92 ; Coins of the Roman Empire in the British Museum, IV (Mattingly), C. H. V. SUTHERLAND, 93; An Archaeological Record of Rome (Ryberg), O. L. RICHMOND, 95; L'Arte in Roma (Ducati), J. M. C. ToynbEE, 96; Greek Popular Religion (Nilsson), H. J. Rose, 97 ; Musae Anglicanae (Bradner), S. Gaselee, 98 ; Some school-books, D. S. Colman, 100.

Short reviews. $\quad . \quad . \quad . \quad . \quad$ IOI

Summaries of periodicals . $\quad . \quad$. $\quad$ ro3

Correspondence . . . . . . 104

Books received $\quad$. $\quad$. $\quad$. $\quad$. 104 